\title{
EFFECTS OF DIFFERENT COAGULANTS ON THE PHYSICO-CHEMICAL, MICROBIAL AND SENSORY PROPERTIES OF WARA, A NIGERIAN SOFT SOY-CHEESE
}

\author{
James $^{1^{*},}$ S., Nwokocha ${ }^{2}$, L., Tsebam ${ }^{1}$, B.C., Amuga ${ }^{3}$, S.J., Ibrahim ${ }^{1}$, A.B., and Audu ${ }^{1}$, Y. \\ ${ }^{1}$ Department of Food Science and Technology, Federal University of Technology, \\ PMB 65, Minna, Niger State, Nigeria \\ ${ }^{2}$ Department of Hospitality and Tourism Management, Delta State Polytechnic, \\ Ogwashi-Ukwu,Delta State, Nigeria \\ ${ }^{3}$ Federal University Kashere, Gombe State, Nigeria \\ *Corresponding author’s email: samaila.james@futminna.edu.ng
}

\begin{abstract}
Nigerian soft cheese often referred to as wara was produced from soya bean milk using coagulants from lime, alum and steep water. Effects of these coagulants on the yield, proximate composition, functional properties, microbial loads and sensory properties were evaluated. The result revealed that different coagulants used had no significant $(p \geq 0.05)$ effect on yield of the cheeses. The result for the proximate composition shows that, different coagulants used influenced all the proximate parameters except the protein content. Similarly, coagulants used significantly affected the water absorption capacity, oil absorption capacity, foam capacity and gelation capacity. However, the bulk density was not significantly $(p \geq 0.05)$ affected. Steep water coagulated cheese had the highest total plate count. The result for sensory properties shows that, lime gave the best cheese in terms of general acceptability. Cheese produced from steep water as a coagulant gave the best proximate attributes, however, its high total plate count calls for concern.
\end{abstract}

Key words: local cheese, proximate, microbial, sensory and functional

\section{INTRODUCTION}

Meat analogues are food products that are made to have similar texture, color, taste and form as meat (Hurley and Liebman, 2006). They are considered to be meat substitutes or meat alternatives because, they provide good source of protein and can also be used as bulking agent to extend real meat products. Meat analogues usually contain flavor, spices and wheat gluten and are rich in fiber because they are made from plants (Klausner, 2002). Wara (a meat analogue) is an unripe cheese consumed in several parts of West Africa. It is often referred to as poor man's cheese and also known as 'tofu', 'beske', or 'wara' in Nigerian. It can serve as a snack which is easy to prepare and often eaten as a main meal.

Locally, meat analogue, wara is made from soybeans (Glycine max). Soybean is a leguminous vegetable belonging to the pea family. It is grown in the tropical, sub-tropical and temperate climates and it is known to have great nutritional value. Its importance ranges from milk production, oil processing, livestock feeds, industrial uses and human consumption (Iwe, 2003).
Soybeans have been recognized to be an ideal grain for meeting protein requirement for both man and animal. It is a source of good fat (unsaturated) unlike saturated fat from animal origin hence, good for heart health (Iwe, 2003; Samuel and George, 2009). Soybean is a cheap source of quality protein that balances the essential amino acids profile of cereal flour and it has a close protein content and amino acids to cow's milk (Belewu and Belewu, 2007). It is one of the best vegetarian food items as far as protein content is concerned. Whole soybean contains $40 \%$ protein, $30 \%$ carbohydrate, $20 \%$ lipid and 10\% mineral (Iwe, 2003; Samuel and George, 2009). The medicinal nature of soybean is extremely essential in building body immune system. Soybean foods have significant protection against such health challenges as heart disease, diabetes, high blood pressure, stroke, menopause, ulcer, and cancer (Singh et al., 1999; Fabiyi, 2006).

Wara processing involves the use of rudimentary equipment and largely a home art method. The process is not standardized and usually done under unhygienic conditions. In some communities, starter culture recovered from 
previous production is kept for the next production; while others make use of lemon juice. These variations account for non-uniformity of the product in terms of nutrients, texture and acceptability. This work attempts to study the effects of different coagulants on the quality and sensory acceptability of the product.

\section{MATERIALS AND METHODS}

\section{Sources of Materials}

The soybeans, alum, lime and steep water were purchased from Kure Ultra-Modern Market, Minna, Nigeria.

\section{Sample Preparation}

Soybean seeds were cleaned to remove contaminants. The seeds were soaked in clean water (for $2 \mathrm{~h}$.) to soften them, washed and then milled into a paste. The paste was diluted with water at ratio 1:4 and sieved through muslin cloth to extract the soy milk.

\section{Production of Local Cheese}

The milk obtained was boiled in a stainless steel pot for $10 \mathrm{~min}$. after which the coagulant (lime, steep water or alum) was added to the boiling soy milk until the proteins clot at their isoelectric point. Coagulated cheese was then pressed in a muslin cloth to remove residual whey, cut into uniform cubes of $3 \mathrm{~cm}$ and deep-fried in a boiling vegetable oil to doneness (7-8 min). Local cheese from each coagulant was refrigerated $\left(4^{\circ} \mathrm{C}\right)$ until analysis.

\section{METHODS}

\section{Determination of Moisture Content}

Moisture content of the samples was determined according to AOAC (1995). A porcelain crucible was washed and dried in a hot air oven for $30 \mathrm{~min}$. at $105^{\circ} \mathrm{C}$. It was then cooled in a desiccator for another $30 \mathrm{~min}$. The crucible was then weighed and $2 \mathrm{~g}$ of the sample was poured into the crucible dish and recorded as $\mathrm{W}_{1}$ and $\mathrm{W}_{2}$ respectively. The crucible and the content were placed in an oven at $105^{\circ} \mathrm{C}$ for $3 \mathrm{~h}$. It was then removed, cooled in the desiccator for $30 \mathrm{~min}$ and weighed recorded as $\mathrm{W}_{3}$.

$$
\% \text { Moisture Content }=\underline{\mathrm{W}_{3}} \frac{-\mathrm{W}_{2}}{\mathrm{~W}_{2}} \times 100
$$

\section{Determination of Fat}

The fat content of the samples was determined according to AOAC (1995). A 2-g sample was carefully transferred into a thimble. The thimble was blocked with cotton wool and the extraction was carried out continuously for $8 \mathrm{~h}$ using petroleum ether (boiling point $60^{\circ} \mathrm{C}$ ). The solvent was evaporated using water bath and the remaining extract was dried at $105^{\circ} \mathrm{C}$ for $60 \mathrm{~min}$ in an oven after which it was placed in desiccator to cool. The flask was weighed again and \% fat calculated thus:

$$
\text { Fat }=\frac{\text { Weight of extracted fat }}{\text { Weight of sample }} \times 100
$$

Determination of Ash Content

The ash content of the samples was determined according to AOAC (1995). The weight of crucible dish was taken and $2 \mathrm{~g}$ of the sample was added to the crucible and place in a muffle furnace rack and the temperature was set to $500^{\circ} \mathrm{C}$ for $16 \mathrm{~h}$ until there was complete ash. The ash in the crucible dish was removed and kept in desiccator to cool before weighing. Percentage ash was calculated as:

$$
\% \text { Ash }=\frac{\text { Total weight of extracted ash }}{\text { Weight of sample }} \times 100
$$

\section{Determination of Crude Fibre Content}

The crude fibre of the samples was determined by the procedure outlined in AOAC (1990). Two $g$ of the sample was weighed into $500 \mathrm{ml}$ beaker and boiled in $200 \mathrm{ml} \mathrm{HCl}(10 \% \mathrm{~V} / \mathrm{V})$ for $30 \mathrm{~min}$. The suspension was filtered and the residue was washed vigorously with distilled water until it was no longer acidic. It was then boiled in $200 \mathrm{ml} 1.25 \mathrm{M}$ $\mathrm{NaOH}$ for $30 \mathrm{~min}$. filtered through Whattman filter paper (No. 1) and then washed with distilled water. The residue obtained was transferred into a pre weighed crucible in hot air oven for $30 \mathrm{~min}$., then cooled in desiccator and reweighed.

$$
\% \text { Crude fibre }=\frac{\mathrm{W}_{2}-\mathrm{W}_{3}}{\mathrm{~W}_{1}} \times 100
$$

\section{Determination of Protein Content}

The protein content was determined by AOAC (1995). Half (0.5) $\mathrm{g}$ of sample was weighed into $500 \mathrm{ml} \mathrm{Kjeldahl} \mathrm{flask.} \mathrm{One} \mathrm{tablet} \mathrm{of} \mathrm{catalyst}$ (Selenium) and $20 \mathrm{ml}$ of $25 \%$ concentration of sulphuric acid $\left(\mathrm{H}_{2} \mathrm{SO}_{4}\right)$ was added and the flask was fixed into Kjeldahl digestion plate. Digestion lasted for $6 \mathrm{~h}$ and the liquid was clear and free from brown or black coloration. The digested mixture was allowed to cool and made up to $100 \mathrm{ml}$ in a conical flash. Two drops of indicator ( $2 \%$ methyl red) was added and placed under the collection spigot of the distillation apparatus. $10 \mathrm{ml}$ of the digester was pipetted into stopper portion of the condenser and $10 \mathrm{ml}$ of $40 \%$ sodium hydroxide solution was added the solution was allowed to distil for $15 \mathrm{~min}$. or when the volume of ammonia collected in boric acid in the receiver flask was $50 \mathrm{ml}$ and when the red solution had turned blue, the distillate was then titrated against $0.1 \mathrm{M}$ hydrochloric acid $(\mathrm{HCl})$ to a pinkish colour. The protein was calculated as:

$$
\% \text { Gramme Nitrogen }=\frac{\mathrm{T} \times 0.014 \times}{\text { Weight of sample }} \times 100
$$

where $T$ is titre value and DF is dilution factor. Multiplying the value of \% Gramme Nitrogen by 6.25 gives \% Crude Protein. 
Determination of Carbohydrate Contents Carbohydrate contents of the cheese samples were determined by difference:

$\%$ Carbohydrate $=100-(\%$ moisture $+\%$ ash $+\%$ protein $+\%$ crude fibre $+\%$ fat)

\section{Functional Properties \\ Bulk density}

The procedure of Adebowale et al. (2005) was used. A specified quantity of the sample was put into a weighed $5 \mathrm{ml}$ measuring cylinder $\left(\mathrm{W}_{1}\right)$. For packed density, it was gently tapped to eliminate air spaces between the sample in the cylinder and the volume was noted as the volume of the sample used. The new mass of the sample and the cylinder was recorded $\left(\mathrm{W}_{2}\right)$. The bulk density was expressed as: $\mathrm{BD}=\mathrm{W}_{2}-\mathrm{W}_{1}$. For loose bulk density (LBD) space was not eliminated by trapping.

\section{Water absorption capacity}

Water absorption was determined using the method outlined by Adebowale et al. (2005). One gram of sample was weighed in pre-weighed $15 \mathrm{ml}$ centrifuge tubes and $10 \mathrm{ml}$ distilled water was added. After the mixture was wetted samples were allowed to stand at room temperature for $30 \mathrm{~min}$. with occasional stirring. The mixture was centrifuged for $25 \mathrm{~min}$. at $3000 \mathrm{rpm}$. The resultant supernatant was decanted and the centrifuge tube containing sediment was weighed.

\section{Foaming properties}

Foaming capacity was measured by mixing $1 \mathrm{~g}$ of sample with $50 \mathrm{ml}$ of distilled water in a laboratory blender and transferred to $250 \mathrm{ml}$ graduated cylinder. The foam formed was indicated as the foaming capacity $(\mathrm{ml} / 100 \mathrm{ml}$ sample). The final observation was made after $60 \mathrm{~min}$. for determining the foam stability (Onwuka, 2005).

\section{Emulsion properties}

Emulsifying property was measured as described by Yatsumatsu et al. (1992) by mixing $0.5 \mathrm{~g}$ of the sample with $5 \mathrm{ml}$ of distilled water followed by addition of $5 \mathrm{ml}$ of oil and vigorously shaken for 5 min. by magnetic stirrer. The resulting emulsion was centrifuged at $2000 \mathrm{~g}$ for $30 \mathrm{~min}$. The volume of the emulsified layer divided by whole slurry and multiplied by 100 resulted in the emulsifying activity ( $\mathrm{ml} / 100 \mathrm{ml}$ of sample).

\section{Gelatinization capacity}

The gelation capacity was determined using the modified method by Kulkarin et al. (1991). A suspension of the sample was made by mixing it with distilled water at ratio 1:4 (W/V) in a $100 \mathrm{ml}$ laboratory test tube. The suspension was heated for $1 \mathrm{~h}$ in a boiling water bath followed by rapid cooling under running tap water. The test tube was further cooled for $2 \mathrm{~h}$ at $40^{\circ} \mathrm{C}$. The test tubes were then inverted one after the other. The least gelation capacity was taken as the concentration when the sample from the inverted test tube did not fall or slip.

\section{Microbiological Analysis}

The microbial load of the samples was determined according to AOAC (1990). Nutrient agar (28 g) was dissolved in one liter distilled water in a conical flask. The dissolved agar was autoclaved at $121^{\circ} \mathrm{C}$ for $15 \mathrm{~min}$. One gram of the sample was weighed and dissolved in a test tube and serial dilution was carried out. One $\mathrm{ml}$ of the dilution was pour plated and incubated for $24 \mathrm{~h}$ at $37^{\circ} \mathrm{C}$. The colonies were counted and recorded as colony forming unit/g.

\section{Sensory Evaluation}

The sensory evaluation of the cheese samples was carried out by 20 untrained panelists from the Department of Food Science and Nutrition, FUT, Minna. Hedonic scale was used with 1 representing 'extremely like' and 9 'extremely dislike'. The panelists were presented with the coded samples and were asked to judge the samples on the basis of appearance, aroma, taste, mouth feel and overall acceptability. The assessors were instructed on the basic taste panel procedures and to make their own individual judgment. They were equally instructed to take a sip of water and pause for a few seconds before tasting each sample and to re-taste if not sure of their decisions.

\section{STATISTICAL ANALYSIS}

Data obtained were analysed using analysis of variance (Steel and Torrie, 1980). Where differences between mean values existed, they were separated using the least significant difference test. Significance was accepted at 5\% probability level.

\section{RESULTS AND DISCUSSION}

\section{Proximate Composition of the Cheese}

The isoelectric point $(\mathrm{pH})$ of protein rich food is an important step in the production of cheese. The final quality of cheese can be affected by the type of coagulum used during the coagulation process. The results of the yield and proximate composition show that the samples significantly $(p \leq 0.05)$ differed in all parameters measured except in yield and protein content (Table 1). There was no significant $(p \geq 0.05)$ difference in the yield which implies that the various coagulants considered did not differ considerably in their coagulating ability. Moisture content of steep water coagulated cheese was significantly $(p \leq 0.05)$ higher than lime and alum coagulated cheeses. These results contradict Omotosho et al. (2011) who reported that cheeses from cow milk had no significant moisture difference in all coagulants used. In such perishable food product, high moisture content is not preferred 
Table 1: Yield and proximate composition of the cheeses

\begin{tabular}{lccc}
\hline $\begin{array}{l}\text { Yield (\%)/ } \\
\text { Proximate } \\
\text { composition }(\%)\end{array}$ & $\mathrm{A}$ & $\mathrm{B}$ & $\mathrm{C}$ \\
\hline Yield & $24.20 \pm 0.01$ & $23.52 \pm 0.11$ & $23.92 \pm 0.02$ \\
Moisture & $25.22^{\mathrm{b}} \pm 1.40$ & $26.68^{\mathrm{b}} \pm 0.34$ & $28.43^{\mathrm{a}} \pm 0.02$ \\
Ash & $3.21^{\mathrm{a}^{\mathrm{a}} \pm 0.02}$ & $2.63^{\mathrm{b}} \pm 0.08$ & $2.74^{\mathrm{b}} \pm 0.10$ \\
Protein & $40.00 \pm 1.21$ & $41.30 \pm 0.00$ & $41.40 \pm 0.41$ \\
Crude fibre & $2.48^{\mathrm{c}} \pm 0.10$ & $2.94^{\mathrm{b}} \pm 0.20$ & $3.12^{\mathrm{a}} \pm 0.10$ \\
Fat & $38.85^{\mathrm{a}} \pm 0.15$ & $33.85^{\mathrm{b}} \pm 0.15$ & $33.85^{\mathrm{b}} \pm 0.26$ \\
Carbohydrate & $8.09^{\mathrm{b}} \pm 1.43$ & $13.01^{\mathrm{a}} \pm 2.65$ & $11.25^{\mathrm{ab}} \pm 0.50$ \\
\hline
\end{tabular}

Values are means of triplicate readings. Values on the same row followed by the same superscript are not significantly different.

A - Lime coagulated cheese, B - Alum coagulated cheese,

C - Steep water coagulated cheese

Table 2: Functional properties of the cheese samples

\begin{tabular}{lccc}
\hline $\begin{array}{l}\text { Functional } \\
\text { properties (\%) }\end{array}$ & $\mathrm{A}$ & $\mathrm{B}$ & $\mathrm{C}$ \\
\hline $\begin{array}{l}\text { Water absorption } \\
\text { capacity }\end{array}$ & $1.25^{\mathrm{a}} \pm 0.05$ & $1.17^{\mathrm{b}} \pm 0.01$ & $1.13^{\mathrm{b}} \pm 0.20$ \\
$\begin{array}{l}\text { Oil absorption } \\
\text { capacity }\end{array}$ & $1.31^{\mathrm{a}} \pm 0.10$ & $1.08^{\mathrm{b}} \pm 0.30$ & $1.35^{\mathrm{a}} \pm 0.13$ \\
$\begin{array}{l}\text { Emulsion } \\
\text { capacity }\end{array}$ & $41.46^{\mathrm{b}} \pm 0.50$ & $42.50^{\mathrm{a}} \pm 0.10$ & $39.47^{\mathrm{c}} \pm 0.74$ \\
$\begin{array}{l}\text { Foaming } \\
\text { capacity }\end{array}$ & $6.00^{\mathrm{b}} \pm 1.00$ & $8.00^{\mathrm{a}} \pm 0.20$ & $4.00^{\mathrm{c}} \pm 0.30$ \\
$\begin{array}{l}\text { Bulk density } \\
\text { Gelation capacity }\end{array}$ & $0.59 \pm 0.14$ & $0.58 \pm 0.02$ & $0.59 \pm 0.01$ \\
\hline & $\mathrm{Gel}$ & $\mathrm{Gel}$ & $\mathrm{Gel}$ \\
\hline
\end{tabular}

Table 3: Microbial load of the cheese samples

\begin{tabular}{lc}
\hline Sample & Total Plate Count $(\mathrm{CFU} / \mathrm{g})$ \\
\hline A & $7.7 \times 10^{4}$ \\
B & $8.4 \times 10^{4}$ \\
C & $1.2 \times 10^{5}$ \\
\hline \multicolumn{2}{l}{ A - Lime coagulated cheese, B - Alum coagulated cheese, } \\
C - Steep water coagulated cheese
\end{tabular}

Table 4: Sensory properties of the cheese

\begin{tabular}{lccc}
\hline Sensory attribute & $\mathrm{A}$ & $\mathrm{B}$ & $\mathrm{C}$ \\
\hline Texture & $7.00^{\mathrm{a}} \pm 0.97$ & $6.30^{\mathrm{ab}} \pm 1.34$ & $6.15^{\mathrm{b}} \pm 1.34$ \\
Flavour & $6.05 \pm 1.73$ & $5.85 \pm 2.00$ & $5.70 \pm 1.75$ \\
Taste & $6.30 \pm 1.59$ & $5.65 \pm 1.87$ & $5.90 \pm 1.99$ \\
Appearance & $6.40 \pm 1.27$ & $6.45 \pm 1.39$ & $6.15 \pm 1.18$ \\
General acceptability & $6.85 \pm 1.03$ & $6.30 \pm 1.62$ & $6.45 \pm 1.79$ \\
\hline \multicolumn{4}{l}{ Values are means of triplicate readings. Values on the same row } \\
followed by the same superscript are not significantly different. \\
A - Lime coagulated cheese, B - Alum coagulated cheese, \\
C - Steep water coagulated cheese
\end{tabular}

because it favours the growth and proliferation of microorganisms, thus reducing the shelf life. The moisture content ( 25.22 to $28.43 \%$ ) obtained in this study is low compared with $38.10 \%, 37.45 \%$ and 49.07 to $49.71 \%$ for PM fruit liquor supplemented gouda cheese, $\mathrm{CO}$ fruit liquor supplemented gouda cheese and Mozzarella cheese, respectively (Andreatta et al., 2009; Choi et al., 2015). The ash content is a measure of mineral elements in a food. The ash content of lime coagulated cheese was significantly high $(p \leq 0.05)$ than alum and steep water coagulated cheeses. This result agrees with
Choi et al. (2015) and Song et al. (1997) who reported a significant $(p<0.05)$ increase in the ash content of gouda cheese supplemented with PM fruit liquor over the control. The ash content in this study (2.63 to $3.21 \%$ ) agrees with 2.57 to $3.95 \%$ for six Mexican cheeses (Caro et al., 2014). Similar trend was observed in the crude fibre content. Lime coagulated cheese significantly $(p<0.05)$ had the highest fat content, while steep water and alum coagulated cheeses had the least values. The significantly $(p<0.05)$ higher fat content of lime coagulated cheese agrees with Choi et al. (2015) who reported an increase in the fat content of cheese supplemented with $\mathrm{CO}$ fruit liquor over the control. The result obtained in this study $(38.85 \%)$ is high compared with 31.22 to $33.52 \%$ and 18.80 to $31.80 \%$ for gouda cheeses supplemented with two fruit liquors and six Mexican cheeses, respectively (Caro et al., 2014; Choi et al., 2015). The carbohydrate content ranged from 8.09 to $13.01 \%$ with alum having the highest value $(13.01 \%)$. Similar result was reported by Choi et al. (2015) in gouda cheeses.

\section{Functional Properties of the Cheese}

Different coagulants significantly $(p \leq 0.05)$ affected all the functional properties (WAC, FC, EC, GC) studied except the bulk density (Table 4). The water absorption capacity of lime coagulated cheese was significantly $(p \leq 0.05)$ higher than alum and steep water coagulated cheeses. This could be attributed to the fact that lime juice did not interfere with the hydrophilic domains of the amino acids thereby giving the cheese high water binding capacity (James and Nwabueze, 2014; James et al., 2016) . The oil absorption capacity of steep water coagulated cheese was significantly ( $p$ $\leq 0.05$ ) higher than lime and alum coagulated cheeses. This implies that, possibly, steep water favoured the hydrophobic domains of the protein giving the cheese characteristics high oil absorption capacity. However, the emulsion capacity of alum coagulated cheese was significantly $(p \leq 0.05)$ high than lime and steep water cheeses. This could be as a result of the presence of residual salt (alum) in the product which increased the solubility of active protein. Furthermore, foaming capacity and stability depend on the surface of active properties of protein involved (Iwe, 2000).

\section{Microbial Load of the Cheese}

Steep water coagulated cheese had the highest total microbial count followed by coagulated cheese from alum, the lime coagulated cheese had the lowest microbial count (Table 3). The high count observed in steep water coagulated cheese could be attributed to the fact that steep water itself contains a diverse microbial flora due to natural fermentation. By contrast, lime juice and alum are low in natural microbial load. 


\section{Sensory Attribute of the Cheese}

There was no significant $(p \geq 0.05)$ difference in the sensory parameters studied except in texture (Table 4). Lime coagulated cheese was significantly $(p \leq 0.05)$ high in texture than alum and steep water coagulated cheeses.

\section{CONCLUSION}

Cheese coagulated from lime gave the highest yield. In proximate composition, the cheeses compared favourably however, lime coagulated cheese had the highest ash and fat content. The sensory attribute -mouth feel of cheese coagulated by steep water was low, with high microbial load.

\section{REFERENCES}

A.O.A.C. (1990). Association of Official Analytical Chemist (15th ed.), Washington DC, USA

A.O.A.C. (1995). Association of Official Analytical Chemist (16th ed.), Washington DC, USA

Adebowale, Y.A., Adeyemi, I.A. and Oshodi, A.A. (2005). Functional and physiochemical properties of flours of six Mucuna species. Afr. J. Biotechnol., 4, 1461-1468

Andreatta, E., Fernandes, A.M., Santos, M.V., Mussarelli1, C., Marques, M.C., and Fernandes de Oliveira, C.A. (2009). Composition, functional properties and sensory characteristics of Mozzarella cheese manufactured from different somatic cell counts in milk. Braz. Arch. Biol. Technol., 52 (5), 1235-1242

Belewu, M.A. and Belewu, K.Y. (2007). Comparative physico-chemical evaluation of tiger-nut, soybean and coconut milk sources. International J. of Agriculture and Biology, 9 (5), 785-787

Caro, I., Soto, S., Fuentes, L., Gutiérrez-Méndez, N., García-Islas, B., Monroy-Gayosso, KE. and Mateo, J. (2015). Compositional, functional and sensory characteristics of selected Mexican cheeses. Food and Nutrition Sciences, 5, 366-375

Choi, H.Y., Chul, J.Y., Choi, K.P. and Bae, I. (2015). Characteristics of Gouda cheese supplemented with fruit liquors. J. of Animal Science and Technol., 57, $15-25$

Fabiyi, E.F. (2006). Soybean processing, utilization and health benefits. Pakistan Journal of Nutrition, 5 (5), 453-457

Hurley, J., and Liebman, B. (2006). Don't have a cow. Nutrition Action Health Letter, 33 (6), 13-15
Iwe, M.O. (2000). Effects of extrusion cooking on some functional properties of Soy-sweet potatoe mixturea response surface analysis. Plant Foods Hum. Nutr. $55,(2), 169-84$

Iwe, M.O. (2003). The Science and Technology of Soybeans: Chemistry Nutrition Processing and Utilization ( $1^{\text {st }}$ ed.), Rejoint Communication Services Ltd. Enugu State, Nigeria, p 680

James, S, Anuonye J.C., Husseini, M, Ede, E.B., Amuga, S.J. and James, Y. (2016). Chemical composition and functional properties of protein concentrate from selected cowpea seeds in Nigeria. EC Nutrition, 4 (3), 857-868

James, S. and Nwabueze, T.U. (2014). Influence of extrusion condition and defatted soybean inclusion on the functional and pasting characteristics of extruded African breadfruit (Treculia africana) flour blends. Food Science and Quality Management, 34, 26-33

Klausner, A. (2002). Throw one on the grill: new "veggie" burgers might surprise you. Environmental Nutrition, 25 (7), 5

Kulkarin, K.D., Kulkarin, D.N. and Ingle, U.M. (1991). Sorghum malt-based weaning formulations, preparation, functional properties and nutritive value. Food Nutr. Bull., 13, 327-332

Omotosho, O.E. and Oboh, G. (2005). Effect of coagulant on the nutritional quality and in vitro multi enzyme protein digestibility of tofu. J. of Food Technology, 3, 182-187

Onwuka, G.I. (2005). Food Analysis and Instrumentation: Theory and Practice ( $1^{\text {st }}$ ed.), Naphtali Publishers, Lagos, Nigeria

Samuel, D. and George, E. (2009). Soybean and Wheat Crop: Growth, Fertilization and Yield ( $1^{\text {st }}$ ed.), Nova Science and Pub., New York, USA, p. 86

Singh, S.R., Rachie, K.O. and Pashiell, Z. (1999). Soybean for the tropics. Acad. Publishing, New York, USA

Song, B.H., Choi, K.S., and Kim, Y.D. (1997). Changes of physicochemical and flavour components of Ume according to varieties and picking date. Kor. J. Postharvest Sci. Technol., 4, 77-85

Steel, R.D.G., and Torrie, J.H. (1980). Principle and Procedures of Statistics: A Biometrical Approach (2nd ed.), McGraw Hill Co., New York

Yatsumatsu, K., Sawada, K.A., Moritaka, S., Misaki, M., Toda, J. and Wada, T. (1992). Whipping and emulsifying properties of Soybean products. $J$. Agric. Biol. Chem., 36, 717-725 